\title{
G. H. Mead and the value of his theory for education
}

\author{
Artur José da Renda Vitorino' (1) \\ Pedro Serafim Anes Pires' (D)
}

\begin{abstract}
This article addresses the psychosocial and pragmatist theory constructed by American philosopher George Herbert Mead (1863-1931) and his value for school education in the present. Throughout a detailed analysis of his works, supported by the works of commenters, Mead is situated in the scholar context of his time, and the precepts of his ideas are delineated in contrast with that of his peers. His legacy consists of a multidisciplinary framework that is intertwined - psychology, sociology, and education, - presented in a clear and accessible language, always having the mediation and construction of one's self as guiding principle, through symbolic interaction. This work is also based on foreign and Brazilian authors who studied the works of Mead and saw his value for education, but offers a different perspective of how the ideas of this philosopher could help address school education issues, such as inclusion, bullying, and the social role of schools.
\end{abstract}

\section{KEYWORDS}

G. H. Mead; pragmatism; education; symbolic interactionism.

'Pontifícia Universidade Católica de Campinas, Campinas, SP, Brazil. 


\section{G. H. MEAD E O VALOR DE SUA TEORIA PARA A EDUCAÇÃO}

RESUMO

Neste artigo são apresentados a teoria psicossocial e pragmatista erigida pelo filósofo americano George Herbert Mead (1863-1931) e seu valor para a educação escolar no presente. Mediante uma detalhada análise da obra, com apoio de comentadores, Mead é situado no contexto acadêmico de sua época, delineando-se os preceitos de seu pensamento e a idiossincrasia entre seus pares. Seu legado consiste num arcabouço teórico multidisciplinar - tratando-se de psicologia, sociologia e educação, interligados -, em uma linguagem clara e acessível, tendo sempre como princípio norteador a mediação e a construção do self, por intermédio da interação simbólica. O presente trabalho também se baseou em comentadores brasileiros e estrangeiros que estudaram Mead, mas oferece um enfoque diferente de como as ideias do filósofo poderiam ser úteis em elucidar questões pertinentes à educação escolar, tais como inclusão, bullying e papel social da escola.

\section{PALAVRAS-CHAVE}

G. H. Mead; pragmatismo; educação; interacionismo simbólico.

\section{G. H. MEAD Y EL VALOR DE SU TEORÍA PARA LA EDUCACIÓN}

\section{RESUMEN}

Este artículo presenta la teoría psicosocial y pragmática erigida por el filósofo estadounidense George Herbert Mead (1863-1931) y su valor para la educación escolar actual. A través de un análisis detallado de su trabajo, con el apoyo de comentaristas, Mead se sitúa en el contexto académico de su tiempo, delineando los preceptos de su pensamiento y su idiosincrasia entre sus pares. Su legado consiste en un marco teórico multidisciplinario - psicología, sociología y educación interconectadas - presentado en un lenguaje claro y accesible, siempre teniendo como principio rector la mediación y construcción del self a través de la interacción simbólica. Este documento también se basó en comentaristas brasileños y extranjeros que estudiaron a Mead, pero ofrece un enfoque diferente sobre cómo las ideas de Mead podrían ser útiles para dilucidar cuestiones relacionadas con la educación escolar, como la inclusión, el bullying y el papel social de la escuela.

\section{PALABRAS CLAVE}

G. H. Mead; pragmatismo; educación; interaccionismo simbólico. 


\section{FROM STIMULUS TO GESTURE}

\section{GEORGE HERBERT MEAD}

The objective world, in a very strict sense, comprises everything that simply exists autonomously and before any perceptions or valuations, and is real, regardless of the subjective evaluation of any agent, and, for this reason, it is objective. Therefore, an exceedingly narrow meaning is incorrectly inferred in the view of George Herbert Mead, an author whose ideas never gave into full-fledged relativism but, likewise, moved away from a positivist "naive realism".

George Herbert Mead was born in the state of Massachusetts, USA, in 1863, being the second son of religious professors. In the second half of the nineteenth century, the American philosophy still closely followed the European philosophy, especially the German one. Aligned with the ideas of Immanuel Kant and his definitions of synthetic and analytic, ideal and transcendental, the following was in vogue at the time: German idealism, as established by Georg Hegel (who died in 1831), and Neo-Kantianism; Marxism, in politics and Edmund Husserl's Phenomenology - a philosophic study of the constitution and dynamics of human psychology, predating Sigmund Freud's psychoanalysis; and Arthur Schopenhauer and Friedrich W Nietzsche who sought the meaning of human existence. These were the origins of continental philosophy, that is, European philosophy, excluding Great Britain; a term used by the English utilitarian J.S. Mill to distinguish the British philosophic tradition - empiricist and utilitarian — from the others (Glock, 2008).

When his father was invited to teach at a university in New Hampshire, Mead moved in with his family, where he stayed for a short period, until his father received a new offer to teach at Oberlin University, in Ohio. Mead spent his youth there, beginning his studies at the same college where his parents lectured (Souza, 2011, p. 372). However, young Mead, upon entering university during a period of secularization, distanced himself from his parents' religious dogmatism. From the early years of his education at Oberlin (Souza, 2011, p. 372), he was familiar with the Darwinian theory ${ }^{1}$ of the evolution of species and the natural sciences as a whole, and followed it. He was a secular thinker, aware of the view that the science of his time presented of the natural world, dismissing any mystical or theological explanations and discarding any dualist assumptions. Therefore, his psychosocial theory never denied the role biology plays in psychology and recognized that it is a necessary substrate for the mechanisms of social interaction and the construction of one's self. Also, he never limited these mechanisms to this sphere.

To understand how it is possible to avoid contradiction, we will consider the concept of intelligence. The natural world is deterministic, but not teleological. This means that it is not the intelligence of a being, whether a species is extinct or not, that determines the configuration of objects in time and space, despite the

1 However, he did no fail to make specific criticisms of Darwin regarding the role of emotions in the gesture, as will be explained later. 
vividness of this illusion. Not even a leaf falls if not for gravity, independent of will or intention, and one cannot speak of intentions and beliefs, unless cautiously in a very abstract sense.

However, in reality, all of the processes that take place in the natural world do so in accordance with natural laws, which isn't to say that they cannot give rise to highly complex systems, leaving the impression that there is an intelligence behind them. However, it is not just the theory of evolution itself that is not intelligent. The first living organisms, many of which still exist, such as plants and fungi, are also not intelligent. A single-celled organism of a species of algae or plankton has a very limited relationship with the world around it, which basically boils down to physical and chemical reactions in their internal environment, and an equally limited capacity to react to minor environmental changes to survive. However, as more and more complex systems emerge, it becomes difficult and unproductive to use the same conceptual repertoire, and the patterns that repeat themselves in some phenomena are only perceived when an appropriate perspective is employed (Pinker, 1998, p. 409).

Intelligence was a complex function that arose through the development of the nervous system in some animals at a certain point in evolutionary history. It was maintained because it is a competitive advantage for these animals; just like the development of gills or trunks was advantageous for others. Mead, however, opposing Draghiscesco's theory of natural science (Joas, 1985, p. 91-92), believed that what makes human beings sui generis in the animal kingdom and allowed social relations to be handled with a different repertoire compared to that employed by the natural sciences, is not intelligence per se, but the way social and non-social objects are presented to human observers.

When he left Oberlin in 1883, his parents were already deceased and Mead had a period of financial difficulties. Separated from his academic career, he supported himself with manual labor, an experience which, as he reported in his personal correspondence (Joas, 1985, p. 16), was both arduous and enriching, awakening his interest in the concrete problems of social life. He returned to academia in 1887 , to Harvard University, and spent a semester studying in Germany, during the winter of 1888-1889, the country that was the center of social psychology (Joas, 1985, p. 17-18), his main area of interest.

A psychosocial perspective is necessary not only when considering very intelligent beings, but also when we consider conscious beings who develop as social animals, which is an anthropological approach to consciousness that Mead inherited from Wilhelm Wundt, one of his mentors in Germany. Such consciousness takes root through social interaction with their peers. Among humans, this interaction takes place through the use of signs, whose study was pioneered by the founder of pragmatism, Charles Sanders Peirce. Mead learned Peirce's theses indirectly through one of his professors at Harvard, Josiah Royce, and refined them side-by-side with his colleague and friend John Dewey ${ }^{2}$.

2 The relationship with their intellectual heirs will be dealt with in more detail in the next section. 
For Mead, psychology does not need to, nor should, abandon the objectivity and its empirical and methodological rigor when addressing other natural perspectives, although a purely mechanistic analysis is also not acceptable, because it risks losing sight of the object of psychology. Nor can it be solipsist, addressing consciousness as if it could exist in isolation. That is, the explanation of mental phenomena and associated behaviors is not reducible to non-mental phenomena, but can be explained as emerging from them.

\section{GESTURE AND ATTITUDE}

Gesture is the central concept for G.H. Mead's pragmatist social psychology. Intelligent animals, including human beings, learn from the environment. They adapt and react intelligently to it, in a context-sensitive way. Individuals constantly receive visual, auditory, and tactile stimuli and all of the objects in the universe are subject to the same sound and light waves, and ground vibrations. However, animals have developed sensory organs, receptors tuned to certain stimuli, ready to initiate an electrochemical reaction, a signal. This signal travels along afferent nerves via the central nervous system, where its transduction and processing produce a signal that causes a change in attitude and a subsequent response from the individual.

Intelligence confers upon the animal the capacity to react to the stimuli that surround it, adapting itself to them through action. This is what makes the gesture what it is. The social gesture, the focus of Mead's work, is used by animals to modify their attitudes towards other animals and adjust to them ${ }^{3}$. Human beings have become particularly adept at gestures.

Mead employs several examples of animal behavior to exemplify this simpler gesture mechanism. In one of his favorite examples, the dogfight, one dog starts growling at the other. The look of the second dog is interpreted as threatening by the first, triggering a process that leads it to respond with a growling gesture to elicit a fight-or-flight fear response in the other. This is the meaning of the gesture, what the dog intends to change in the environment through a gesture.

The gesture provokes a change not only in the opponent, but before that, in the first dog: bared teeth, saliva, and a rush of adrenaline that speeds up its heartbeat. At the same time that it externally influences the opposing animal, the gesture influences forms ${ }^{4}$ within the body and mind of the first dog. The second dog may respond by attacking or may growl louder, a gestural conversation. The outcome of a social act initiated by a gesture can be the inception of another gesture.

Human beings also engage in simple gesture conversations, without language, and do so habitually. A driver signals with a turn signal their intention to change lanes, and then changes lanes without causing an accident. This simple action hold the essence of the gesture, its threefold structure from which meaning

3 The thesis defended by the author is that every gesture has a social foundation.

4 The author's use of the term "form" is similar to what cognitive science currently calls mental and cerebral "modules", to indicate semi-autonomous elements of the mind or its physical substrate. 
arises (Mead, 1940, p. 268). The meaning of the gesture in this example is, primarily, in its relationship to the driver who initiates the desired action; by initiating the gesture, they stimulate their own minds to go ahead with the action, knowing that they are safe. At the same time, the gesture relates itself to the behavior of the other drivers, who, when they perceive the intention of the first driver after having seen the turn signal on, change their attitude, responding with other gestures, to leave that side of the road free. Finally, the process relates to the outcome (that is, the pragmatic result of the action) of the driver changing lanes without hitting another vehicle.

Without the three relationships, one cannot really speak of gesture. A small child, negligently forgotten in a car by his father, begins to play with the lever of the turn signal. Despite doing something physically similar, he is not performing an action that communicates his intention - the act he wants to perform - neither to himself nor to others (he is alone in the car). This is simply because there is not an intention or an outcome that changes the attitude of the child ${ }^{5}$, who also does not know the meaning behind the turn signal. A gesture always implies an interaction in which there are behavioral adjustments between internal and external forms (Mead, 1940, p. 71). However, to be a significant gesture, it is necessary to have an idea behind it, a meaning.

\section{MEAD'S POSITION ON BEHAVIORISM}

Mead always regarded behaviorist psychology with respect, not the approach of his fellow countryman J. B. Watson ${ }^{6}$, but mainly the one from German W. M. Wundt, who he met while studying in Germany. Mead inherited from Wundt the concept of gesture (Mead, 1940, p. 13) and recognition of the importance of culture in the development of human beings. He considered the work of both to be a necessary stage in the development of psychology as a science and its separation from mentalist precepts of the past (Mead, 1940, p. 21-23). However, he sharply criticized this behaviorist paradigm.

Mead found it too superficial, since it solely addresses the physical behavior of the object of study, be it human or animal; a perspective always "from the skin outwards", which is limited to making correlations between stimuli that occur to a subject during an experience and the subsequent observable changes in behavior. This paradigm is known as parallelism, which, according to an experiment that Watson said to have conducted, would supposedly be demonstrated by the acquisition of phobias through the association of neutral stimuli with other unpleasant stimuli. In Watson's experiment, a phobia of rats would have been induced into a child by frightening the child with a noise at the same moment that the rat approached.

5 Even if a person passes by the parking lot, notes the turn signal, and becomes concerned with the baby abandoned in the car, this would not be a symbolic relationship because it lacks the intent of the actor.

6 Watson also lectured in Chicago, after 1890. The rivalry of the thinkers led to a split between the psychology and philosophy departments, with Mead remaining in philosophy (Souza, 2011, p. 375). 
In addition to being exceptionally unethical, the conclusion that Watson drew from this experiment is questionable. Cognitive scientist Steven Pinker (1998, p. 409), among others, (Bisaccioni and Carvalho Neto, 2010), claims that all phobias are directly or indirectly related to primal fears, which cannot be induced in relation to completely neutral objects. This refers to the idea of impulses or instincts inherent to human nature, social instincts; ideas which Mead adopts (with some caution) from William McDougall (Joas, 1985, p. 92-94).

Watsonism, a pejorative term used by Mead to refer to his rival's approach to behaviorism, reduced the mind to a series of conditioned reflexes, learned through repetition, disregarding any subjective phenomena, and greatly oversimplifying the individual's mental effort in interpreting their situation (Mead, 1940, p. 101).

The problem begins when one considers the time between stimulus and response. Long before a gesture begins - and becomes clearly observable - the subject initiates several attitudes in preparation. Before pushing the turn signal, a driver releases some of the fingers from the steering wheel, moves them closer to the lever, and rests one or two fingers on the lever. Before actually releasing his hand from the steering wheel, he must have an idea of where he wants to go and how to do it, and how to do it safely. For example, which gestures are needed to be performed so that the other drivers, each on their own respective course, are allowed to follow that course. None of these phases of the act makes sense without considering the action as gestures that reflect attitudes. Also, they do not make sense without considering that such gestures are phases of a social act.

Watsonian behaviorism can explain why the driver signals to the right, but not why he decided to drive from his house in the city of Campinas to a certain street in São Paulo. Thus, as explained above, planning is difficult to predict. Dewey (1896 apud Joas, 1985, p. 66) argued that seeing stimulus, processing, and response as isolated elements - the reflex arc concept — is a mere causality and a temporal, not causal, correlation. This mistakenly presents the subject's mind as a passive entity, as if its preconceptions and preexisting expectations did not determine the responses, or as if the stimuli to which the subject is attentive and reacting were not previously selected by the attention mechanism.

In addition to being action-oriented, Mead was most interested in the methodology, another facet of naturalism: behaviorism proposes to exclude metaphysical complications (Mead's term) from the scientific analysis of the subject, an objective third-person view, considering only what can be evaluated in the third person, excluding vague terms related to subjective phenomena, such as feelings, dreams, drives, and traumas, which European schools of thought, such as phenomenology and psychology, were full of. For behaviorists, what arises from introspection (by the psychologist or their object of study) and is derived from the Cartesian notion of "mind and body" is left out of the analysis. The mind is always understood as a result of evolution, through which some reflexes that were more advantageous to survival prevailed, with a "ghost in the machine" explanation.

As contemporary functionalist philosopher Daniel Dennett (1995, p. 80-83) affirmed, perspective is not a question of denying the existence of minor elements 
in a system that have their own reality, nor saying that the larger system has a metaphysical existence, but to abstract them for study purposes, to find patterns that allow understanding and predicting the system's behavior. For example, one can study a city's traffic while ignoring the details of how a combustion engine works, with the phenomenon being better understood from the top of a tall building rather than from the middle of a busy street. Similarly, the mind and its phenomena are as real as its organic substrate, the brain, and should be studied without reductionisms.

Mead adopted this materialist perspective ${ }^{7}$, but he understood that it was excessively judgmental, leading to overly superficial and individualistic analyses and giving very little importance to both the social environment and the reflexivity of the self, of its own consciousness.

Mead held Wundt in much higher esteem. The German psychologist's concept of gesture and the linguistic theory that emerged from his Volkerpsychologie social psychology consisted of an important foundation for Mead's ideas which, at the beginning of his career, he accepted without criticism in his first essay on Volkerpsychologie, (Joas, 1985, p. 94-96).

However, his thinking diverges from that of Wundt in important aspects. In his second essay on the subject, Mead felt that Wundt's concept of apperception was very similar to parallelism in his understanding of intersubjectivity, and relied too heavily on the concept of imitation (this issue will be explored in more detail in the next section) without even considering the intelligence that intermediates stimulus and response; a gap that the American author would fill with symbolic interactionism.

As for intersubjectivity, without discrediting Wundt, a pioneer concerning this scientific psychology paradigm, Mead identified it as a problem of his Volkerpsychologie (Mead, 1940, p. 49-50) based on the assumption that the self and the mind exist a priori, in a hypothetical and initial solipsist mental stage in the formation of the individual, before being influenced by consequent social interactions. For Mead, the difference is that social interaction precedes consciousness and the self only comes into existence at this point, not when an individual is born (Mead, 1940, p. 49).

The value of the subjective perspective in the understanding of the human mind is still considered an unresolved issue. Perhaps this is the main reason for the conflict existing between analytical and continental philosophy, and even within analytical philosophy, which strives for precision when choosing terms, and objectivity and clarity when expressing ideas. How reliable are subjective reports if subjective experiences have properties - synthesized by the term qualia ${ }^{8}$ — rendering the subjective experience irretrievably private and ineffable? And the question raises a doubt: "How do I know whether my red is the same as your red?" Sometimes even

7 Distancing him considerably from the thinking of pragmatist William James.

8 Coined by C. S. Peirce in the nineteenth century, but becoming more evident in the 1980s and 1990s, with the advances in cognitive science and the approximation of the discussion between philosophers and neuroscientists. 
the most eminent philosophers seem to argue over these dilemmas without hinting that they are talking about the same thing.

Avoiding metaphysical themes, Mead proposed to analyze behavior, considering its internal elements, forms, and dynamics of interaction, as well as interaction with the society in which it is found. His understanding of subjectivity comes from reflexivity, from seeing the other in oneself, elements that make the human mind unique within the animal world. However, parallels with animal behavior are useful, and Mead constantly draws upon them, even though animal gestures do not differ much (even if they are, effectively, gestures), beginning with learning them.

\section{HUMAN AND ANIMAL BEHAVIOR}

Animals are born with various predispositions to gestural interaction, as well as an aptitude for learning new gestures and new associations. One common explanation - both in Mead's time and in the present - is that animals simply learn by imitation, as in the proverb "monkey see, monkey do". However, Mead refutes this explanation. Imitation is not very prevalent in the animal world, being more common among human beings (Mead, 1940, p. 51).

Let us say a parrot learns to sing a song, a jingle that is repeated over and over again on TV. The parrot is not trying to imitate the television, it likes the song. A stimulus provided by an external form provokes a reaction in the parrot, and it begins to reproduce sounds, with its own vocal apparatus, until it is capable of producing a sound that pleases it. The bird needs to repeat it a few times and knows it has been successful when the sound he produces provokes the response produced by the television. There is no identification that leads to imitation, but an adaptive adjustment of the subject's behavior, and in this case, what caused the first stimulus does not matter, whether it was another parrot, a bird of another species (like a sparrow imitating a canary without even being aware it was doing so, according to Mead's original example (Mead, 1940, p. 66), or an electronic object.

A case that is only superficially similar to that of the parrot - and a better example of imitation - would be that of a Brazilian student trying to learn English. In one class, he tries to learn how to pronounce the phoneme $\theta$, one of the ways to pronounce the digraph "th", which is particularly difficult for Portuguese speakers. He hears and sees the teacher pronouncing "thing", and tries to say "thing" as best he can. The teacher is not satisfied and repeats "thing". The student, paying attention to the sound of the word and the movement of the teacher's lips, tries again and pronounces it a bit better.

There is something more in this activity than learning by assimilating a stimulus; something which Mead believed did not exist among animals - at least not as sophisticated as among humans: the identification with the other and the understanding of the other person's attitudes in comparison to their own (Mead, 1940, p. 67). The student understands that he is a being from the same species as 9 As explained by the fruitless debate between Searle and Dennett (Searle and Dennett,
1995). 
the teacher, with the same vocal apparatus and (to a certain extent) the same cognitive apparatus. He does not only learn to say "thing", but to use the word "thing". He truly learns that when the word begins to have the same utility for him as it has for the teacher when composing vocal gestures, which he can use to influence other individuals and adjust his conduct.

\section{FROM GESTURE TO SIGN}

One of the three structures of a vocal gesture, the relationship between the gesture and the speaker, is more important in a vocal gesture than in a simple (non-symbolic) one, and this is peculiar to the human species. One should also consider the planning behind a vocal gesture that is based upon adopting a perspective. One dog growling at the other does not cause - or does not necessarily cause - fear in the dog who growled, as it causes in the second. It does not depend on the first dog to understand and put itself in the shoes of the other, it is only an instinctive gesture without deliberation (Mead, 1940, p. 63).

The same could be said of the parrot that learns to sing a jingle from TV, of bees in a hive looking for nectar to make honey, and even of human beings in various situations in which an automatic and unthinking response is necessary (Mead, 1940, p. 178-179); such as soldiers fighting a battle and obeying rigid training, or employees in a stereotypical Ford-style production line. However, the unmistakable idiosyncrasy of human social behavior is the result of their capacity for symbolic mediation, which enables them to plan future actions, much farther in advance, and carry them out with precision. This depends on recognizing the other and learning implicitly relies on such recognition, not on mere repetition (Mead, 1940, p. 118-119).

It is very difficult for humans to understand what goes on in the mind of an animal despite the ability of the human brain to manipulate abstract symbols and plan. Pet owners get really frustrated at this, a philosophical problem that always surfaces when animal rights are debated.

Philosopher T. Nagel (2015) also addressed this problem in his paper Como é ser um morcego? (What Is It like to be a bat?), in which the author demonstrates how difficult it is to put oneself in the perspective of an animal and really know what it is like to be a creature with such a different cognitive structure.

\section{SIGN AND SYMBOL}

G.H.Mead's three-tiered definition of symbol and his approach to semiotics is, in general, similar to that of C. S. Peirce:

I define a sign as anything which is so determined by something else, called its Object, and so determines an effect upon a person, which effect I call its interpretant, that the latter is thereby mediately determined by the former. (Peirce, 1893-1913 apud Atkin, 2013, § 1). 
Bibliographical citations, such as those in this work, can be taken as an example of a sign, as briefly defined by Peirce in the previous citation. The pair of parenthesis containing the first capital letter and four numbers has as its object the bibliography of this paper, which means that it determines the sign, whereas, the effect on the reader - looking at the final pages and reading what is written - is its interpretant $\mathrm{t}^{10}$. The interpretant is not the individual as a whole who captures the sign, but what Mead called interior form, and more specifically, the interior form, in an abstract sense, when the sign is being interpreted; in the reader's mind when the reader visualizes and interprets the pair of parenthesis containing a word with a capitalized letter and a four-digit number (or a driver who sees the turn signal blinking in the car in front of him).

Citations have different characteristics, and each one would still be a sign, even if some of the characteristics were different: they could be blue, be written in another font, be printed or on a computer screen. However, only some of their characteristics are important (being within parenthesis, containing a capitalized first letter and numbers, etc.), because only these characteristics determine the conditions for the causal nexus between the object and the sign, and between the sign and the interpretant. The set of a sign's defining characteristics can be called sign-vehicle, representation, representamen, among other synonyms (Atkin, 2013), and is normally referred to simply as a sign by Peirce.

The sign can be an icon, index, or symbol (Santaella, 2002, p.13; Atkin,2013). An icon is simply an object that resembles another, such as a photograph, while an index possesses a sensory or causal relationship - a common story - other than resemblance. Simple associations of cause and effect, so important to behaviorism, and which the mind of a non-human can make, fit into these categories.

Especially regarding his theory as presented in Mind, self and society ${ }^{11}$, Mead always returns to a biological perspective to address semantic relationships based on what was known at his time about the structure and functioning of the nervous system ${ }^{12}$, with which he was very familiarized. The nervous system sends electrochemical stimuli from the sensory organs and the body towards the central nervous system, provoking sensations.

Mead also knew that certain synaptic connections between neurons could be reinforced as they were activated, creating neural pathways that were more likely to fire in response to each other. This mechanism of synaptic reinforcement would, in the twentieth century, be summarized by the phrase "neurons that fire together wire together". The simple reflexes, which all animals perform and are capable of learning through repetition routines, and whose stimuli would be classified as icons

10 Not the act itself, but the effect produced in his mind which eventually leads him to an act, in Peirce.

11 About which, without denying its value, criticisms were raised. See Joas and Huebner, 2016.

12 The Spanish histologist Ramon Santiago y Cajal first identified the neuron, with its arboreal molecular structure comprised of dendrites and axons, in 1897; a few years after Mead began to lecture at the University of Chicago. 
and indexes according to Peirce, can be more easily explained from a biological perspective.

When we begin to address the symbols themselves, whose association must be learned, and which can be employed in different situations, a more precise explanation is needed. Words are a significant symbol. They are stimuli that look nothing like their referent; they do not even have an existential connection with it. They need to be learned.

\section{ATTENTION AND LEARNING}

William James (1918, p. 403), in chapter 9 of his classic work Principles of Psychology, highlighted the fact that, of the "millions of items of the outward order" present in your senses, few make it into your conscience, for the simple reason that it is not interested in them. Mead, in turn, detected how perception is a movement that originates from an act in progress, but involves a momentary interruption of this act to contemplate options for continuity, keeping itself integrated into the gesture flow. As an act of perception, like vision, a coordinated sequence of eye movements, changes in pupil size, and the coordination of a complicated movement to bring the light of the target object onto the center of the retina (Joas, 1985, p. 149).

Modern cognitive science supports the understanding that perception is never immediate, but always mediated. When the torrent of sensory signals converges in the thalamus, it immediately undergoes an initial filtering process that separates signal from noise, then the thalamus forwards the stimuli of each modality to their respective cortices (Sternberg and Sternberg, 2016, p. 34). In the case of visual stimuli from the optic nerves, they converge in the optic chiasm, and from there in the thalamus, where they arrive inverted (the signal from the left eye goes to the right hemisphere and vice versa) in the primary visual cortex $(V 1)^{13}$. Here, there are sets of neurons specialized in recognizing colors (V4), forms, luminosity (V1), which are activated by certain patterns, such as lines, vertices, and intersections. Two pathways exit the primary visual cortex. One is ventral, connected to the temporal lobes, where what is being viewed is interpreted; and the other is dorsal, which leads towards the parietal cortex, which is concerned with localizing object spatially (Dehaene et al., 2006; Sternberg and Sternberg, 2016).

The temporal lobe cortices are also responsible for interpreting and contextualizing auditory stimuli, whether they are meaningless sounds or meaningful words and phrases. These regions of the brain, located, as the name suggests, in the temples, house the innermost part of the amygdalas. With the shape and size of a pea, these organelles are tuned to the symbolic processing executed in the temporal lobe cortices, provide emotional intonation corresponding to perceived situations, and influence decision making and the state of attention according to one stimulus or the other (Damásio, 2009, p. 35-36).

13 In the occipital lobe, the most frontal part of the brain, behind the nape of the neck. 
The pre-frontal cortex, the most forward part of the frontal lobe, right behind the forehead, is full of pyramidal neurons, mainly concentrated on the outermost surface of the encephalon, which are rich in dendrites (receptors tuned to the activity of the rest of the brain) and axons (that innervate the rest of the cortex and sub-cortex, like administrative buildings covered by antennae, coordinating the activity of the rest of the body). As Antônio Damásio (neuroscientist, philosopher, naturalist, and Baruch de Spinoza scholar - like Mead) explains, the primary pre-encephalitic structures make maps that correspond to the actual state of the body, its homeostasis. The Portuguese author calls this first representation protoself ${ }^{4}$, while the cortical structures that codify symbols work to maintain this homeostasis, properly understand the context and future opportunities, and remember past events. According to Damásio (2009, p. 83-86), these events are always memorized along with the relative emotional state. This is better illustrated by the following diagram (Figure 1).

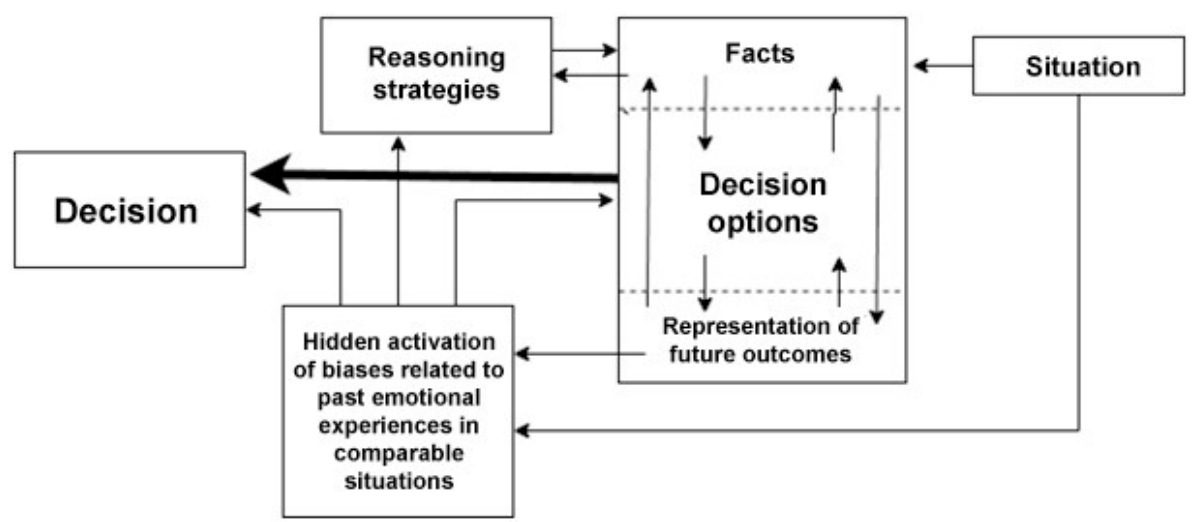

Source: Prepared by the authors, faithfully reproduced from the book Em busca de Espinosa (Looking for Spinoza) (Damásio, 2009, p. 86).

Figure 1 - Flow of decision making.

This is very similar to the four-phase action model proposed by Mead: impulse, perception, manipulation, and consummation (Joas, 1985, p. 148-149) — in that order. The impulse to act can be understood as a predisposition held by an individual, even before facing a new situation or which may lead to one, of which he or she may or may not be aware, and which influences perception. The memory of what has occurred before, organized into signs and mental symbols, as well as the memory of how good or bad the specific situation and the individual's decision were, directly influence what Mead referred to as manipulation - the process illustrated in the large box of the diagram. This structured memory, aided by reasoning, intermediates consummation when facing a new episode.

The pragmatists, including Mead, were on the right track when considering an organic arc - in which the act is comprised of different modules that dynam-

14 Mead would certainly object to this choice of words! 
ically interact, each one determining the other — and understanding meaning as a two-way process. Advocating for the use of psychostimulants ${ }^{15}$ in children and adolescents who have pathological difficulties in sustaining attention in class and remaining still is spurious given that the role of the pre-frontal cortex in attention and learning is very well characterized, as well as the importance of the neuromodulator dopamine for the effective functioning of this cortex. It is an unfounded criticism against the "medicalizing of life", but it almost always contains biases and simplistic opinions about the actual problem ("shame on you", "at my time, this would be solved with spanking"). Cartesian dualism lies at the heart of this bias, the idea that there is something ethereal and almost supernatural in mental phenomena.

However, it would be equally spurious to say that a biological disorder is the only possible explanation when students face disciplinary or motivational problems. Concerning attention, Mead is exactly correct in describing humans as attentive animals, whose attention can be directed to the most subtle stimuli (Mead, 1940, p. 25). Humans can understand the importance of the stimulus and redirect their neurocognitive apparatus to that stimulus.

The student who tries to learn how to pronounce the phoneme $\theta-$ and this example can be extrapolated to any other teaching relationship - does not only have to recognize an equivalent in the teacher, but must also understand the relevance of the activity. If he is unable to concentrate on this exercise - or ignores the teacher, choosing to look out of the window - it may be because he is not interested in the subject or is not capable of recognizing the importance that learning English might have for his future. The lack of perspective that fuels the lack of motivation - including in students without any neurological disorder - is not uncommon in schools.

However, this reasoning raises questions: how do we decide what kind of knowledge is useful? Can the veracity of what is taught be qualified as a value in and of itself? And also, what makes knowledge true? Austrian philosopher Ludwig Wittgenstein was especially concerned with the latter.

\section{LANGUAGE AND CONTEXT}

In his Tractatus logicophilosophicus, Ludwig Wittgenstein (2001, p. 165) wrote:

Man possesses the ability to construct languages with which all meaning can be expressed, without having any idea on how and what each word means - just as we speak without knowing how particular sounds are produced.

Common language is part of the human organism, and is no less complicated than it.

It is humanly impossible to extract from it, in an immediate way, the logic of language.

15 In particular Ritalin, the commercial name for methylphenidate, which is most often used to treat Attention Deficit Hyperactivity Disorder (ADHD). 
Language is a costume that disguises thought, and does so in such a way that it is not possible to infer from, the outside shape of the costume, the shape of the disguised thought. This is because the outer shape of the costume was formed for entirely different purposes to make the form of the body recognizable.

The tacit agreements that allow understanding common language are enormously complicated.

Regardless of how different are George H. Mead's ideas compared to those of the Austrian philosopher quoted in the epigraph in this section - coming from a later generation and with an analytic tradition - it is not difficult to see the similarities in this excerpt from Tractatus: the admission of the complexity of language, the impossibility of immediately extracting its logic, and the implicit admission of "aptitude without knowledge" with which people use it. Though not all human communities developed or adopted written language, none of them were mute. Until the mid-twentieth century, most of the world's population was illiterate, but nearly the entire world population knew how to speak and listen, even if they had never attended a grammar class. However, there are also important divergences between Mead and the Wittgenstein of Tractatus, and one of them is the assumption that languages are created.

The pragmatist program of anchoring the reality of facts in their practical consequences leads to the understanding that language is a human and social phenomenon. Wittgenstein, whose concerns, and the role he placed upon philosophy, differ from those of the pragmatists, admitted that language does not exist in isolation. Not only are languages learned through social interactions, but they are also essential for introspective cognition itself.

The multiplicity of pragmatic results which a word, or string of words, can provoke in different people, at first glance, seems to be a challenge to pragmatism. For example, the word "cigarette" may signify "death", "disease" or a "waste of money" for a non-smoker who hears it, in an informal conversation, when someone suggests going to the smoking area. And their attitude does not change at all, they simply answer, "No thanks, I'll stay here". At the same time, for a smoker who participates in the same conversation, a cigarette signifies something desirable, causing a change of attitude and conduct; the person will leave, following the one who suggested the smoking area.

Wittgenstein referred to this type of interaction as "language games", and although he probably never came into direct contact with Mead or Dewey's thinking (as he did with James'; Haack, 1982), one can note that his focus on the problems of language and his concern for clearing up misunderstandings is, to a certain point, pragmatic. However, before dealing further with Wittgenstein, the origins of his branch of philosophy must be discussed, developed parallelly to pragmatism, but with which it has striking similarities.

\section{THE FIRST AND SECOND WITTGENSTEIN}

For Wittgenstein (2001, p. 135), in his Tractatus, "the world is the totality of facts, not things", and a fact consists of the configuration of things. Things - or 
objects - are simple (Wittgenstein, 2001, p. 139), and the way they relate, intertwining like the links in a chain, is their logical structure in the state of affairs, and the structure of the facts - whose totality is the world - arises from the state of affairs (Wittgenstein, 2001, p. 141).

Wittgenstein's epiphany and what inspired him to write Tractatus is believed to have been a magazine article (Costa, 2002, p. 24-27) which described - or depicted - a traffic accident, first with a model, then with a verbal description. What do the accident, the model and the text have in common? When we make a statement about some worldly fact, we make a figuration, which is a model of reality (Wittgenstein, 2001, p. 143), and behind this figuration - that wraps it - is a proposition. A proposition is a representation of a worldly fact, imitating its logical form, in an isomorphic relationship between the elements of the proposition and worldly objects. A proposition can, however, exist only as a logical form, without any real-world counterpart, and can categorically affirm that which is not a fact.

Note that Wittgenstein's concern in Tractatus is to establish the logic of predicates and how to determine their validity, but he says little about how to definitely prove the truth of figurations and propositions, how to know if a proposition corresponds to a fact in the concrete world, and this task seems impossible simply considering its extent.

Wittgenstein drew upon the logical atomism of his mentor Edmund Russell, but was more skeptical regarding the power of logical analysis, pointing out that a figuration may or may not represent the reality, and that we can only verify whether its meaning - what it represents - is true when comparing it with the reality. But how do we make a comparison to know whether we are hearing a true sentence and not a lie or a piece of fiction?

However, the unsuspecting reader is wrong if he concludes that he is dealing with an archetypical philosopher in his proverbial ivory tower, after reading Tractatus and coming across the simplistic way the author seeks, admittedly, as his predecessors did, to resolve the problems of philosophy using the logic of language only. In addition to Tractatus, Wittgenstein wrote another book, published posthumously (at his request), entitled Philosophical investigations, in which he makes various corrections and poses questions, restoring the importance of natural language and taking a position much closer to naturalism and pragmatism itself, as philosopher Robin Haack points out.

In launching the concept of language games, he accepted the importance of the context in determining the meaning of a proposition; context, as Dewey wrote, is a "body of beliefs and institutions, and the practices associated with them" (Dewey, 1969, p. 106 apud Haack, 1982, p. 106).

He recognized the importance of behavior in properly understanding meaning; how the effect that propositions have on the interlocutors depends on how they understand the concept, and, most of all, the importance of all interlocutors agreeing to "playing the same game". The crucial difference, as Haack points out, is in the role Wittgenstein assigned to philosophers. He affirmed that philosophers should not serve science or let their work interfere in the functioning of society, which 
goes radically against the pragmatist philosophy program. Despite Wittgenstein's uncontested importance for Western ideas in the $20^{\text {th }}$ century, analytic philosophers of the present time still disagree on this indifference. Whoever performs their role clarifying ideas and resolving problems should not only expect, but also assume responsibility for the repercussions, and serve as an example to listeners. This responsibility is based on getting at the truth, even though it is neither unique nor contained in a single mind.

For Mead, similarly, the truth and its universal character are not found in the mind of a single individual nor can it be understood in a purely abstract form, disregarding the social context. It is inserted in a common world (Joas, 1985, p. 75). However, in dealing with truth and objectivity, one must be careful to avoid a very common and pernicious mistake.

\section{OBJECTIVITY AND THE RELATIVISM TRAP}

The debate over education in Brazil is in a deadlock, but not for lack of trying to promote its progress; countless debates within and outside of academia - TV debates with panels of specialists, as well as heated discussions among laypeople on social networks - have never arrived at a consensus. Certain words are heard and repeated ad nauseam: ideology, indoctrination. One side asserts that the role of schools is simply to teach - teaching being limited to passing on knowledge, avoiding personal opinions - while the other side argues that it is difficult to separate teaching from one's own opinions, asserts the importance of the plurality of ideas, and defends the school's social function — sometimes identifying the very concept of "passing on knowledge" as obsolete or merely a separate task. There are a lot of useless controversies, in the midst of which someone inevitably proposes a "remedy" that is actually a poison: a relativist, moral, and epistemological stance, frequently associated with an incoherent tradition, normally designated by the umbrella term "post-modernism" (Glock, 2008, p. 232).

The relativist stance is mistaken, in the first place, because it is impossible to defend something without being in contradiction. If the truth does not exist, or even, in a solipsist variation, "everyone has their own truth", no knowledge is better than any other and, therefore, everything that is taught both in and out of schools is an opinion, or a mere social construction - which in and of itself is an affirmation that purports to be true. If on the one hand, as the previous section tried to demonstrate, logic alone is insufficient to make a true statement (not merely internally consistent or knowable), without logic, it is impossible. It is neither necessary nor desirable to adopt a relativist stance or to pit school's social role against its educational role; not if we heed Mead, as well as Dewey and the pragmatists of his day - though not necessarily those who came later.

Returning to Joas's analysis (1985, p. 145-146), it was not an easy task to reconcile his conviction in pragmatism and his intersubjectivity for the construction of the self, but he was successful in the end, having distanced himself from the convictions of parallelism that conscious states are a static - or isomorphic 
- representation of reality. Instead, they are really a flow of signals being routed through various nodes in the central nervous system in a continuous process of perception and various fixations of content. Mead avoided the opposite danger of relativism - that of naïve, positive realism - and stayed away from the notion of a self that is perfectly demarcated from the outside or even from the body itself, the Cartesian illusion.

For Mead, the concept of truth has an intimate connection to the construction of the self. Through symbolic interactionism, human beings share knowledge, which is organized into symbols that index sets of sensations and reactions. The outcome of some gestures becomes consensual and the objects that we manipulate, as well as those that we construct, have their unanimous meaning based on how useful they are to our gestures. Take gun advocates, for example, who argue that "guns do not kill people, people kill people". Strictly speaking, they are right. However, the implied suggestion that guns are merely neutral objects and that it makes no sense to regulate their possession, carrying, and sale, is completely wrong. In the first place, they are called weapons because it is understood that they are, principally, made to kill; designed and manufactured to facilitate the act as effectively as possible, and it is for this reason that they are objectively called weapons.

\section{FINAL CONSIDERATIONS: MEAD AND SCHOOL EDUCATION}

Agreements exist about names and concepts - symbols - that become universal so that they can be effectively applied in the organization of an individual's attitudes in social acts, which is only possible when the symbol is universally accepted (Mead, 1940, p. 146). In school, when certain conditions are met, children are introduced to this conceptual universe that lies before them. This takes place by listening to the teacher's words and reading what is written on the blackboard, assimilating the symbols that will help the children to interact in a common world and culture. As Cledes A. Casagrande (2014, p. 97) expressed it:

The action and rationality model intuited by Mead is linked to the concrete need to resolve everyday problems that emerge in community life at the level of culture, practical life, and material life. In this situation, education emerges as an organized community response to the question of how to teach its new members to resolve the concrete problems of the various dimensions of life as effectively as possible.

By receiving this new information, children are not only adding new skills to their selves, but are actually forming them, by increasing the possibility of performing different activities. By learning Mathematics, they gain more autonomy in spending or saving their allowance; by learning to read and write, they can broaden their mental repertoire by reading books or, as many children do, by beginning with comic books. By getting to know different situations through signs of people they do not know, children's minds become increasingly less restricted 
to the limited reality of school, family, and community, and more familiar with the culture of the world, through the words of distant people. Through signs, and by sharing a common human nature, they grow more than they otherwise would if they were prisoners to the limited range of familiar information of their immediate reality.

When we think of the school's social role, we must keep in mind that the school's "traditional" role is also a social one. The better it is performed, the greater its success in forming competent, autonomous individuals to live in a society and not be a burden to it.

Some branches of the so-called post-modernism seem not to realize that their credos negatively interfere by rejecting the value of universally acceptable and useful true knowledge, by emphasizing identity politics, exaggerating their appreciation of traditional cultures - regardless of how much they are based upon mysticism, absolute obedience to tribal authority, or simple belief — and labeling knowledge by its geographical origin, using terms such as "Eurocentric perspective" and reducing science to an "oppressive discourse" (Glock, 2008, p. 232-242). On the contrary, regardless of who has made a discovery or invented a new technology, the pragmatic criterion is sufficient to validate or invalidate a concept. It does not matter who thought of it first or where, and one does not do minority groups any favors by denying them this knowledge, quite the opposite. Medieval thinkers, from the scholastic tradition, already knew how to make this distinction to recognize the value and study the writings of Plato and Aristotle, which they had access to through papyri preserved by the Arabs. Regardless of their "pagan" past and origin, the knowledge in those writings was good and valid.

As important as Casagrande's book G. H. Mead Eं a educação (G. H. Mead and education) (2014) has been for the writing of this work, it is necessary to point out a few flaws in his analysis. He is correct in writing that learning is always an interactive process, and that education should never be seen as a mere pouring of knowledge into the students' minds. The human mind, in effect, is not a blank slate. However, at the same time, the author seems to have some of the vices of the constructivist pedagogy, which usually errs on the side of caution. He repudiates the "old pedagogy" that used to preach a passive, silent learning process, in which the teacher speaks, and the students, at most, could raise their hands to ask a question (Casagrande, 2014, p. 89) - rejecting terms like "passing on knowledge" and emphasizing the process as a joint construction of meanings.

In fact, these are not the best terms to describe the learning process, but the author's error lies in disregarding the lack of symmetry between the teacher and the student in terms of each one's repertory. It would be a truism to say that the teacher knows more than the students. One does not have to reject the interactive nature of the relationship between the educator and the student to accept that part of the interactive process consists of tedious lessons of silent learning and memorization; knowledge that the student can rationalize and use in their life, in and out of the school. Learning takes place through the interpretation of symbolic gestures, but is not limited to vocal or locomotive activity. Students sitting at their 
desks and listening to a lecture, or leaning over a book, are not static and passive: they are aware and an intense dialogue takes place in their minds between their various interior forms during assimilation.

Now we will take a cautious look at an article that is vehemently critical of constructivism in general (Haase, Júlio-Costa and Lopes Silva, 2015). Some of the criticisms it contains are corroborated by scientific evidence, especially regarding the order to teach syntax and semantics. The authors argue that the canon of conservatism errs in condemning the teaching of a word's meaning before, or at the same time as, the identification of its letters, syllables, and respective phonemes, known as the phonic method, championed and proven by neuroscientist Stanislas Dehaene (2009, p. 212), among others; and overloading the immature minds of young learners, forcing them to learn and "think critically" to an excessive extent - arguing that they could learn much more easily if they did not have to "reinvent the wheel". The article is correct on this point, since the great advantage of cultural transmission is not having to spend time and energy on problems that have already been solved.

Of course, even a teacher who adheres to the constructivist approach could accuse the authors of this article of treating this school as a "horror story", arguing that they never follow things so rigidly and simply "leave the students to learn on their own", and that they are ignoring the social role that is independent of political and partisan ideologies. This article - as any academic work based on G. H.Mead's perspective - also intends to show the importance of, and adequately describe, the social role of educational institutions.

A school is a privileged place, dedicated to knowledge. The classroom is of unquestioned importance, but learning does not take place in the classroom only. At school, students are placed in an environment that is completely different from the cozy and familiar one at home. Students also converse and play. In their interactions with other children and adults, they discover conflicts; in games, they learn to take on other roles and perspectives. For this reason, the authors of this article do not look favorably upon the current trend for homeschooling that, despite being illegal, has thousands of followers in Brazil (Moraes, 2019).

Mead's understanding of school is very different from that expressed by the more commonplace interpretations of Foucault, that may not do justice to the French thinker, but regardless of that, are astonishing for being so common in Brazilian academia and for the negative way they portray schools: as a prison that locks children away to subdue them (Ferrari, 2008).

Mead in no way thought of schools as a form of kidnapping, but rather as an extension of the family relationship, and did not understand them as a method for taming, but socializing. In his understanding, not only had human life expectancy increased, but the duration of the childhood had extended far beyond the biological childhood. At the same time, there is much more accumulated culture and information to be learned, so family education, though still very necessary, was no longer sufficient (Mead, 1940, p. 241). In the words of his disciple Charles W. Morris, in the introduction of Mind, self and society (Mead, 1940, p. 34): 
The pragmatist's emphasis on education is the logical corollary of their ethical theory: Education must provide the technique by which moral-intelligent and socialized - selves should be developed. Mead's articles on education highlight five points:

1) The school's importance in giving common meanings, common linguistic tools.

2) The place of science in the curriculum.

3) The need for manipulative activities, responding to the sense of reality in the contact phases of the act.

4) The importance of play to support taking on the roles of others, from which the self is constructed.

5) The role of the school in forming moral selves.

At home, every child, with or without siblings, is special, and in general, receives special treatment. João and José are brothers and they can fight for the attention of their mother and father, but their parents have adapted their daily lives to give each one undivided attention and meet their needs. Outside the home, children are introduced to an environment with stricter rules, schedules, and tasks, in which they are placed on an equal footing with other children (beginning with the uniforms). Therefore, children adapt — some more easily than others - trying new gestures, seeing whether the results of their gestures are desirable or not, and constructing their selves.

This influence weighs much more heavily than any other upon the psychological construction of the self. As Steven Pinker (2003, p. 472-506) affirms in The blank slate, the nature versus nurture debate should have been settled long ago, since the ways genes and the environment interact are well known; which traits are shaped by one or the other, and that genetics encodes tendencies, not predestinations. In fact, a false dichotomy is affirmed to exist between genes, shared environment (with family members, the home), and non-shared environment, visited by an individual and where he has a unique experience. Several experiments that followed twins that were separated at birth and adopted by different families attest that the influence of upbringing is minimal, compared to that of genes and the unique environment, and the way the individual positions him or herself in a group (Pinker, 2003, p. 472-506). Mead had no way of knowing that because he lived and died a few decades before Watson and Crick first glimpsed the helical structure of the DNA molecule, but he had no reason to worry. His naturalist and interactionist views did not conflict; to the contrary, biology eventually confirmed the social disposition and unraveled the mechanisms behind symbol processing and its role in the construction of the self.

This can take place in a destructive way, as is the case with the age-old phenomenon that only gained notoriety in the twenty-first century, known as bullying (Schultz et al., 2012), in which children's worst instincts cause them to select some within the group as being unworthy, whether because of a physical or behavioral peculiarity, or for racial, social class, or other differences. The final result is almost 
always the same: the child absorbs the idea other people have of them, as a useless, incapable, submissive person. For a long time, schools were remiss about the problem. "Oh, just ignore them" was the response many victims of bullying heard when they complained to teachers or school authorities; as if they were mature enough to do so, as if an adult (who is not a sociopath) could tolerate living in a place where they were humiliated and mistreated, and get disturbed about it. However, when dealing with children, the trauma is always more profound, the image that is constructed in this initial phase is very difficult to change and causes the person to develop in the worst way possible.

Maybe this attitude of neglect has been the prevailing pattern for a long time, not because of indifference to the well-being of children, but because of ignorance as to how negative this type of phenomenon is. Much of this could have been avoided if every teacher or school authority knew, even if superficially, how the self is formed, how the school environment is critical to it, and the role of adults in intervening in these situations - promoting healthy competitive activities, such as games in physical education classes, Mathematical Olympiads, and essay competitions. In these, competitiveness is used to encourage every child to try to win by engaging in healthy activities and satisfying themselves by reaching their potential; not to sabotage them through the efforts of others or to diminish or bully them. Healthy competition is also a way to encourage cooperation within teams, generating experiences that make all the difference in the psychological well-being of an individual and their place in society.

These personal relationships, present in G. H. Mead's theoretical model, allow us to understand that respect for people is one of the far-reaching moral principles, since feeling respect for people, in a more abstract sense, is to be induced by the idea that the other person is, after all, someone like us, who, as such, should deserve the right to be treated with consideration. That is, Mead employs elements of pragmatism to show that the formation of the self requires that equality and difference coexist within social interaction processes, which will allow or not individuals to develop a healthy relationship with their selves.

\section{REFERENCES}

ATKIN, A. Peirce's theory of signs. In: ZALTA, E. N. (ed.). The Stanford encyclopedia of Philosophy. Stanford: Stanford University, 2013. § 1.

BISACCIONI, P.; CARVALHO NETO, M. B. Algumas considerações sobre o "pequeno Albert". Temas em Psicologia, Ribeirão Preto, v. 18, n. 2, p. 491-498, 2010. Available at: http://pepsic.bvsalud.org/scielo.php?script=sci_arttext\&pid=S1413389X2010000200022. Accessed on: Nov. 28, 2021.

CASAGRANDE, C. A. G. H. Mead \& a educação. São Paulo: Autêntica, 2014.

COSTA, C. F. Filosofia da linguagem. 4. ed. Rio de Janeiro: Jorge Zahar, 2002.v. 5.

DAMÁSIO, A. R. Em busca de Espinosa. Tradução Laura Teixeira Motta. 2. ed. São Paulo: Editora Schwarcz, 2009. 
DEHAENE, S.; CHANGEUX, J.-P.; NACCACHE, L.; SACKUR, J.; SERGENT, C. Conscious, preconscious, and subliminal processing: a testable taxonomy. Trends in Cognitive Sciences, Cambridge, v. 10, n. 5, p. 204-211, maio 2006. https://doi. org/10.1016/j.tics.2006.03.007

DEHAENE, S. Reading in the brain: the science and evolution of a human invention. 1. ed. New York: Viking, 2009.

DENNETT, D. C. Darwin's dangerous idea: evolution and the meanings of life. New York: Touchstone, 1995.

FERRARI, M. Michel Foucault, um crítico da instituição escolar. Nova Escola, São Paulo, 1 out. 2008. Available at: https://novaescola.org.br/conteudo/1522/michelfoucault-um-critico-da-instituicao-escolar. Accessed on: Aug. 1, 2019.

GLOCK, H. J. What is analytic Philosophy? Cambridge: Cambridge University Press, 2008.

HAACK, R. Wittgenstein's pragmatism. American Philosophical Quarterly, Oxford, v. 19, n. 2, p. 163-171, abr. 1982. Available at: https://www.jstor.org/stable/20013953. Accessed on: Nov. 28, 2021.

HAASE, V. G.; JÚLIO-COSTA, A.; LOPES SILVA,J. B. Por que o construtivismo não funciona? Evolução, processamento de informação e aprendizagem escolar. Psicologia em Pesquisa, Juiz de Fora, v. 9, n. 1, p. 62-71, jun. 2015. https://doi.org/10.5327/ Z1982-1247201500010008

JAMES, W. The principles of Psychology. 1. ed. New York: Henry Holt and Company, 1918.v. 1.

JOAS, H. G. H. Mead: a contemporary re-examination of his thought. Tradução Raymond Meyer. Cambridge: The MIT Press, 1985.

JOAS, H.; HUEBNER, D. R. The timeliness of George Herbert Mead. Kindle Ed. ed. Chicago: The University of Chicago Press, 2016. E-book.

MEAD, G.H. Mind, self and society. 3. ed. Chicago: University of Chicago Press, 1940.

MORAES, I. Educação domiciliar: o homeschooling deve ser permitido no Brasil? [S.l: s.n.], 2019.

NAGEL, T. Como é ser um morcego? Cadernos de História e Filosofia da Ciência, Campinas, v. 15, n. 3, p. 245-262, jan./jun. 2015. Available at: https://www.cle.unicamp. br/eprints/index.php/cadernos/article/view/617. Accessed on: Nov. 28, 2021.

PINKER, S. Como a mente funciona. 2. ed. São Paulo: Companhia das Letras, 1998. PINKER, S. The blank slate: the modern denial of human nature. 2. ed. New York: Penguin, 2003.

SANTAELLA, L. O que é semiótica. São Paulo: Editora Brasiliense. 1983.

SCHULTZ, N. C.W.; DUQUE, D. F.; SILVA, C. F.; SOUZA, C.D.; ASSINI, L. C.; CARNEIRO, M. G. M. A compreensão sistêmica do bullying. Psicologia em Estudo, Maringá, v. 17, n. 2, p. 247-254, jun. 2012. Available at: https://www.scielo.br/j/pe/a/3 s8Bkbw8Bc9nFR96vZj45Mm/?lang=pt\#. Accessed on: Nov. 28, 2021. 
SEARLE, J. R.; DENNETT, D. C. The mystery of consciousness: an exchange. The New York Review, New York, v. 42, n. 20, dez. 1995. Available at: https://www.nybooks. com/articles/1995/12/21/the-mystery-of-consciousness-an-exchange/. Accessed on: Nov. 28, 2021.

SOUZA, R. F. George Herbert Mead: contribuições para a história da psicologia social. Psicologia \& Sociedade, Belo Horizonte, v. 23, n. 2, p. 369-378, ago. 2011. https://doi. org/10.1590/S0102-71822011000200018

STERNBERG, R. J.; STERNBERG, K. Psicologia cognitiva. Tradução Marcelo Fernandes da Costa. 2. ed. São Paulo: Cengage Learning, 2016.

WITTGENSTEIN, L. Tractatus logico-philosophicus. Tradução, apresentação e estudo introdutório Luiz Henrique Lopes dos Santos; Introdução Bertrand Russell. 3. ed. São Paulo: EDUSP, 2001.

\section{ABOUT THE AUTHORS}

Artur José da Renda Vitorino has a doctorate degree in History from the Universidade Estadual de Campinas (UNICAMP). He is a professor at the Pontifícia Universidade Católica de Campinas (PUC-Campinas).

E-mail: arturvitorino@uol.com.br

Pedro Serafim Anes Pires is graduating in Filosophy from the Pontifícia Universidade Católica de Campinas (PUC-Campinas).

E-mail:pedro.sap@outlook.com

Conflicts of interest: The authors declare they don't have any commercial or associative interest that represents conflict of interests in relation to the manuscript.

Funding: The study was sponsored by Scientific Initiation Support Fund (Fundo de Apoio à Iniciação Científica - FAPIC), a grant from the Pontifícia Universidade Católica de Campinas (PUC-Campinas).

Authors' contribution: Conceptualization, Data Curatorship, Writing - First Writing, Writing - Reviewing and Editing, Research, Methodology, Obtaining Funding, Resources: Vitorino, A.J.R.; Anes Pires, P.S. Supervision: Vitorino, A.J.R.

Received on October 15, 2019 Approved on April 9, 2021 